\title{
USING POLITICAL RIGHTS LEGAL LIABILITY IN SELECT THE OPERATION OF ELECTORAL SHURA (ELECTIONS) IN INDONESIA
}

\author{
Nur'I Yakin Mch. \\ Islamic University of Indonesia \\ nurlyakin@yahoo.com
}

\begin{abstract}
The increasing number of White Group (Abstentions) in every election in Indonesia which is the country's lack of nomokratic indicates people in using their voting rights. When attempts were made government in various ways such as dissemination of the importance to follow the election, but still a high percentage of non-voters there are indications tend to increase. Not only that, a lot of people who misinterpret and fail to understand what is meant in the legislation on the use of the right to vote in the election, it may be because the law is written textual status right but not the obligation to vote. This study uses an empirical juridical approach. law is not only seen as rules or rules, but also includes the operation of law in society. The research specification is analytical descriptive, because this research is intended to provide a detailed, systematic and comprehensive description of all the good things of the legislationWhile the Shura offer an alternative in solving this problem, namely the implementation of laws obligation to choose a leader.
\end{abstract}

Keywords: Legal Liability, Politics Law, Shura Elections.

\section{A. INTRODUCTION}

Citizens' political rights include the right to elect and be elected, the guarantor of rights been expressly set out in the 1945 start of Article 27 paragraph (1) and (2); Article 28, Section 28D (3), Article 28E (3); 14. While the right to vote is also stipulated in Article 1 (2); Article 2 (1); Article 6A (1); Article 19 paragraph (1) and Article 22C (1) of the 1945 Constitution in the formulation of these Articles are very clear that unjustified discrimination regarding race, wealth, religion and ancestry. Every citizen has the same rights ${ }^{1}$ and implementation of rights and obligations must be together.

In the Law on Elections, namely Act No. 7 of 2017, mentioned in Article 198, paragraph 1, which reads: "citizen who on election day are fulfilled age of 17 (seventeen) years or older, married, or have ever been married have the right to choose". Obviously the words included are "right", not "responsibilities".

\footnotetext{
${ }^{1}$ Andri Winjaya Laksana and Suratman, "Analisis Yuridis Penyidikan Tindak Pidana Pornografi Di Era Digitalisasi," Jurnal Pembaharuan Hukum I, no. 2 (2014): 169-77.
} 
Higher up, the supreme law of the country the product is the Constitution of 1945 which was amended in 1999-2002, also stated similar things. In Article 28 E stated: "Election held directly, public, free, confidential, honest and fair elections every five years". The right to vote here embodied in the word free. That is free to use or not is up to voters.

According Ramdlon Naning, human rights can be distinguished $\mathrm{in}^{2}(1)$ rights of private (personal right); (2) The economic rights (property rights); (3) political rights (political rights); (4) rights to equal treatment in law and government (right of legal equality); (5) rights, social and cultural rights (social and culture rights); and (6) rights to equal treatment before the law in the way of justice and protection (procedural rights).

Article 25 of Act No. 12 of 2005 on the Ratification of the International Covenant On Civil And Political Rights (International Covenant on Civil Rights and Political) said that the Indonesian state to recognize and protect the right of every citizen to take part in the implementation of public affairs, the right to vote and be elected, as well as the right of access to public services.

On 28 October 2005, Indonesia ratified the International Covenant on Civil and Political Rights (ICCPR) or the International Covenant on Civil and Political Rights with the passing of the Law on Ratification of the International Covenant on Civil and Political Rights. Covenant is confirmed specifics of human rights in the field of civil and political set forth in the Universal Declaration of Human Rights (Universal Declaration of Human Rights) to become the provisions which are legally binding and its descriptions include a number of other related, Covenant consists of a preamble and Articles which includes 6 chapters and 53 Articles $^{3}$,

Act No. 23 of 2014 in conjunction with Act No. 32 of 2004 on regional administration, Government Regulation No. 6 of 2005 on the selection, approval, appointment and dismissal of the head and deputy head of the region and the General Elections Commission Regulation No. 10 of 2008 on governance for the preparation of the voters list for the election of parliamentarians, regional council and legislature states that a citizen has the right to choose

2 H.Rosjidi Ranggawidjaja, Restriction of Constitutional Right of Citizens to Choose and Selected in the Public Position Journal-Constitution PSKN FH Padjadjaran University, Volume II, Number 2, November 2010, Jakarta, FH Unpad with the Constitutional Court, p. 38.

3 Ibid. 
when Indonesian citizens who have reached the age of 17 (seventeen) years or more or have never been married. Further arranged that the voter list referred to at least the national identification number, name, date of birth, gender and address of Indonesian citizens who have the right to vote.

According Rosjidi Ranggawidjaja, such restrictions can be categorized as a procedural requirement. Whatever the requirements established would constitute a restriction on the right to vote of citizens. ${ }^{4}$ And in the end this will be a reason to do constitusional review of the legislation, because it is clear that the right to elect and be elected a citizen guaranteed by the Constitution and should be protected and given by the state. But in the Electoral Law and the implementing regulations under it provide age restrictions, procedural until administration.

According to the provisions of Article 23 paragraph (1) of Law Number 39 of 1999 on Human Rights (HAM) declared that "Everyone is free to choose and have his political beliefs". Furthermore, according to the provisions of Article 43 paragraph (1) of Act No. 39 of $1999^{5}$; (1) Every citizen has the right to choose and vote in elections based on equal rights by voting in a direct, public, free, confidential, honest and fair manner in accordance with the provisions of the legislation (2) Every citizen has the right to participate in government by directly or through freely chosen representatives, according to the manner specified in the legislation. (3) Every citizen can be appointed to any position in the government. Both the provisions of Article above clearly indicate the inherent juridical guarantee for every citizen of Indonesia itself to exercise the rights memilihnya.dinyatakan that "Every citizen has the right to choose and vote in elections based on equal rights through direct voting, general, free, confidential, honest and fair in accordance with the provisions of laws and regulations". Both the provisions of Article above shows only the right word, so that I may arise "understanding nyoblos or not it was right for my rights" so it seems no expense to participate in the success of the democratic party and the political euphoria in the country. This is because the understanding of liberal democracy that makes society as citizens too freely in the Bohemian nation. Consequently no entanglement between voters selected, because nature is indifferent to cast his vote. which raised the understanding ${ }^{\wedge}$ I may nyoblos or not it was right for my

4 H. Rosjidi Ranggawidjaja, restricted, op.cit., p.113

${ }^{5}$ Act No. 39 of 1999 on Human Rights (HAM) 
rights $^{\wedge}$ so it seems no expense to participate in the success of the democratic party and the political euphoria in the country. This is because the understanding of liberal democracy that makes society as citizens too freely in the Bohemian nation. Consequently no entanglement between voters selected, because nature is indifferent to cast his vote. which raised the understanding ${ }^{n}$ I may nyoblos or not it was right for my rights ${ }^{n}$ so it seems no expense to participate in the success of the democratic party and the political euphoria in the country. This is because the understanding of liberal democracy that makes society as citizens too freely in the Bohemian nation. Consequently no entanglement between voters selected, because nature is indifferent to cast his vote.

Whereas in determining a leader, one vote left to influence who will become future leaders. So that when the selection is not appropriate or even reckless not choose to incompatibility reasons that the potential leaders have made opportunities for other candidates advanced performance leader. While the candidates do not necessarily have the characteristics of a good leader and fair. Do not until later blamed the leaders when leading a country when people initially indifferent to the fulfillment of the right to vote. during elections. In addition, as citizens should have an active and aware of the importance of using the right to vote so as to produce a leader who can deliver state objectives namely the achievement of public welfare ${ }^{6}$,

Normative or doctrinal legal research using a philosophical approach (Philosophy Approach), a comparative approach (Comparative Approach) and the conceptual approach (Coceptusl Approach). The subject matter is as follows; Why the electoral law was not able to effectively prevent the occurrence of abstention ?; how the shura system encourages Muslims to use the right to vote in elections; how the regulation of elections that voting rights be a legal obligation in the elections in Indonesia ?.

\section{B. RESEARCH METHOD}

This study uses an empirical juridical approach. law is not only seen as rules or rules, but also includes the operation of law in society. The research specification is analytical

6 Norm Kelly and Sefakor Ashiagbor, 2011, Political Parties and Democracy in Theoretical and Practical Perspectives. National Democratic Institute, Washington, DC, p. 3 
descriptive, because this research is intended to provide a detailed, systematic and comprehensive description of all the good things of the legislation. Secondary data is data obtained based on literature study intended to compare between the theory and the reality that occurs in the field through this literature study sought data collection through studying books, magazines, newspapers, articles and the internet as well as other references related and related to this study, secondary data in this study include: primary, secondary and tertiary legal materials. Given the limited costs, time and energy of the author, not all populations are examined. The research was only conducted on those who were selected as respondents. $^{7}$

\section{RESULTS AND DISCUSSION}

The high cost $^{8}$ general elections were also highlighted in each time the holding of the democratic party, namely the election. Although this is a routine every five years, but the cost involved countries remained large. Costs are really not kidding. In terms of countries, the total budget for the electoral process of 2014 to reach 17 trillion. Its IT system alone reached $40 \mathrm{bln}$. Not to mention the money gelontoran each candidate, candidate and party to promote him. However, expensive-malahnya these costs, remain more expensive chaos and anarchy. A democracy costs that inevitably have to be paid to avoid this state of disarray without the system and leader. With the use of such enormous cost of elections which should directly proportional to the results of the election are desirable, ${ }^{9}$,

On the other hand, the Shura system offers a pretty good alternative to overcome the problems being faced by the country of Indonesia, especially in terms of the use of the right to vote in elections. Shura system requires that individuals and communities to appoint and elect candidates for leader as a responsibility he would be the importance of sound that he had to take part in determining the future who will become future leaders and elected ${ }^{10}$,

7 Anis Mashdurohatun, "Perlindungan Hukum Merek Batik Menuju Aec 2015 (Suatu Studi Merek Batik Di Kota Pekalongany' Jurnal Pembaharuan Hukum I, no. 2 (2014): 132-43.

8 Anis Mashdurohatun, 2017, Hukum Kontrak, Ekonomi Syari'ah Dan Etika, Undip Press, Semarang, p. 36

${ }^{9}$ Kemenkumham. Politics and the Indonesian Democratic Party Election 2014. Toward the Journal of Legislation Indonesia Vol.9 p.509 4 December 2014.

${ }^{10}$ This interpretation of the classic interpretation that emphasizes his interpretation of verses tasyri' and clicking istinbath-kan laws of fiqh and ijtihad mentarjihkan partly over others. 
In the Qur'an Surat an-Nisa' Paragraph 58 explains that God commands Muslims to convey the message to those who deserve it, and lays down the law among people fairly. 'According to Ibn al-Adil in his commentary Lubab ${ }^{11}$ that Allah commanded the believers in this verse to fulfill all the trust in the various affairs, both with regard to religion and relating to the world. What was stated by Ibn 'Adil shows that the command which includes selecting a leader is a command that must be done ${ }^{12}$.

Therefore, the believers will never take the attitude of non-voters in choosing a leader to know that choosing a leader is an obligation not right ${ }^{13}$, As a liability, then the believers definitely choose the best leaders of the candidates are there because this is reality, so a believer does not deserve to escape from reality. On the other side of the Indonesian Ulema Council (MUI) issued a fatwa abstention in the elections, which indirectly (mafhum mukholafah) also formed a new law is required to vote in elections for anyone who meets the requirements ${ }^{14}$.

The scholars agreed that establishing a state is very important in Islam. Even daulah position or state has reached a milestone maslahah dlaruriyah, no longer just hajiyat or even just tahsiniyat. Determination of the status of emergency" This is not based on a political factor for their kepenting pragmatic interests of some scholars. The status arise solely because of considerations relating maslahah ammah lives of many people. Without the State,

11 This commentary was among the best commentaries are included in the group with a history interpretation (tafsir bi al-ma'sur), that interpretation is basing his interpretation on the narrations and Asar-Asar considered absurd for the verse, the verse well marfu ', mauquf , maqthu ', and the only news received from the Jews (isra'iliyyat story).

12 As-Suyuti collect-wording wording gharib in his work entitled al-Itqan. This commentary can be named as Tafsir Gharaib.

${ }^{13}$ Yusuf Al-Qaradhawi, 2007, Fiqih Maqashid Syari'ah (Moderasi Islam Antara Aliran Tekstual Dan Aliran Liberal), Terj. H. Arif Munandar Riswanto LC., Pustaka Al-Kautsar, Jakarta, p. 221

${ }^{14}$ This commentary was written during the period 1953-1964. Sayyid Qutb interpretation can say using tahlili because he interpreted the Qur'an late sequentially verse by verse, letter after letter, from the first chapters to the last chapters, follows the order of the Ottoman Manuscripts by calling out the first group of verses later interpret. Exegesis is sometimes done on a full paragraph, but often passages cut according to the condition of the verses are interpreted. See Ali Hasan al-'Ard, History and Methodology of Tafsir, (Jakarta: King Grafindo Persada, 1994), p. 41. 
human life will not prosper. Or more specifically, without the State, Islam only in name. From this and the status to be increased to the level of ma'lum min al-din bi al-dlarurah. ${ }^{15}$

The importance of a state as indicated by al-Ghazali located at the position as the guardian of religion. The benefit of the Muslims is a matter of faith and Islam. Therefore, for the sake of Islam, the scholars looked obligatory establish a state that can preserve the religion (haris). Al-Mawardi added that the law lifting a leader is required for ijma', given the leadership is prophetic successor. Even in a tradition affirmed that a leader is mandatorily ${ }^{\text {"1 }}$ Allah in the earth (zill Allah fi ardih) ${ }^{16}$,

Ibn Taymiyya also clearly states the importance of appointing a leader. He predicted that a country without a leader figure, in an instant would be destroyed. Whatever the nature and character of the leader figure should still be appreciated. He asserted that sixty years under the leadership of a despot is much better than one night without a leader "Sittuna sanah min imam ja'ir aslah min laylatin bi la sultan." Ibn Taymiyya statement has become the basis of this reason the birth of a MUI fatwa abstention ${ }^{17}$,

In addition to the logical consideration, the scholars are also not uncommon to base a state obligation on a rule of jurisprudence, ma la yatimm al-wajib illa bihi fa huwa wajib. As a country, could not stand on its own without any leadership. Thus, the obligation to appoint a leader from this perspective becomes mandatory.

Al-Farra stated, "Lifting priest obligatory. Ahmad bin Hanbal, as quoted by al-Khallaf and al-Farra' insists, is catastrophic (slander) if there is no priest who manage the affairs of mankind." (wa al-fitnah idha lam yakun imam yaqum bi amr al-nas). Al-Amidi said "school of Ahl al-Haqq among Muslims claimed that the Imam and his followers raised the legal obligatory for Muslims. ${ }^{n}$ Ibn Hazm al -Andalusi stated, ${ }^{n}$ All Ahlussunnah agree on the necessity of the Imamate. People shall be subject to the priest just and uphold the laws of God in the midst of them, and take care of them with sharia laws. ${ }^{\wedge 18}$

Legal liability priest raised a little different and most manarik among others are set by al-Baghdadi states, ${ }^{\wedge}$ Surely the Imamate ruling fard for the people in order to raise the

\footnotetext{
15 Ifdhal Kasim, 2001, Hak sipil dan Politik Esai-Esai Pilihan, Ed. 1, Lembaga Studi dan Advokasi Masyarakat (ELSAM), Jakarta.p 50.

${ }^{16}$ Ibid.

17 Ibn Taymiyya, 1980, Al-Siyasah Al-Syari' ah, Dar Al-IImp, Cairo. 177

18 Abu Ya la Al-Farra', 1963, Al-Ahkam Al-Sulthaniyah, Mustafa Bab Al-Halabi, Cairo, p. 89
} 
priest. ^ Al-Baghdadi claimed that founded the State (Imamate) became mandatory in order to raise a leader. At first glance it is no different for eventual conclusion is the same. However, al-Baghdadi looked more priority obligation on the appointment of a priest in the establishment of a state. Very logical indeed, because a country without a priest may not exist, but their priests without any concept of the state will still be able to walk ${ }^{19}$,

In addition, the paradigm of thinking is also based on a passage in Qs. al-Nisa [04]: $59^{20}$, Which states the obligation of the believers to obey Allah, obey the Messenger, and to the government (ulu al-amr).

Active political participation occurs when a person has a political awareness and confidence in the government is high then this one's political participation tends to be active. Apathetic political participation occurs where the opposite condition with active participation. If someone has a political awareness and a low confidence in the government, political participation tends to be passive-depressed (apathy). Militant political participation (radicals) occurs when a person has a high political consciousness, but trust in the government is weak then the behavior that appears is the radical militants. Passive political participation occurs when a person has a political awareness ${ }^{21}$ very low, but confidence in the government is very high then this participation is called inactive (passive).

Category abstentions are hard to explain fit into the model of political participation which. Explanation model of political participation of Paige over at least raises two possibilities abstention behavior as a model of political participation is passive and apathetic nature of political participation. Passive political participation by Goel in Efriza ${ }^{22}$ is defined as passive supporters (Passive Supporters) which means that individuals who choose regular or irregular, attend patriotic parades, pay all taxes, and loved the country. Model passive political participation is also expressed by Charles Andrain and James Smith in Efriza ${ }^{23}$ who see a person's political involvement, namely the extent to which people see politics as something

9 Ibid.

20 Qur'an Dan Terjemahnya, (Jakarta: Ministry of Religious Affairs: 2015)

${ }^{21}$ Sri Endah Wahyuningsih, 2014, Restorative Justice System-Di Tingkat Penyidikan Tindak Pidana Lalu Lintas, Tunas Puitika Publishing, Brebes, p. iv

22 Efriza, Political ... op.cit., p.175

23 Ibid., p. 182 
important, have an interest in politics, and often discuss political issues with friends. Berbedalagi the opinions Efriza ${ }^{24}$ who looked passive participation is participation only on the output-oriented, in the sense of simply obeying government regulations ${ }^{25}$, Accept and implement any decision of the government alone.

Category apathetic apathy expressed by Lester Milbarth means people who do not participate and withdraw from the political process, while apathy (Aphatetic inactives) according to Goel is individuals who do not move in a participatory manner, and never pick ${ }^{26}$, Efriza himself concluded apathetic group participation as an abstention because it considers the political system has deviated from what is aspired. A clearer picture can be seen based on the opinions Dedi Irawan in Efriza ${ }^{27}$ linking theory with the participation of the political system. Participation theory stands in the input process which consists of demand and support as well as output. Here is an overview of political participation linkages with the political system that explains the position or location of active participation, passive participation, and participation of known apathy or abstention (non-voting behavior):

1) When members of the public do support and demands to the political system, in truth he has acted active political participation. Active political participation is when members of the public made a proposal on a common policy, propose different public policy alternatives to the policies made by the government, criticism and improvement straighten policies, pay taxes and elect government leaders.

2) The activities included in the activities that receive, obey and implement whatever is decided by the government's policy is referred to as passive political participation activities.

3) (Debatable) is the party that does not do participate, either actively or passively are those who consider the public of the existing political system has deviated from what they aspire. This group is referred to as apathy or abstention (non-voting behavior) ${ }^{28}$,

24 Ibid.

25 I Gusti Ayu Ketut Rachmi Handayani et al., "Relationship between Energy Consumption in International Market and Indonesia Prices Regulation," International Journal of Energy Economics and Policy 7, no. 5 (2017): 9-15.

26 Ibid., P.175

${ }^{27}$ Ibid., P.179

${ }^{28}$ Ibid., P. 179 
Jeffery M. Paige's theory above is explained things basic and theoretical nature, therefore the authors try to complement and enhance the Political Awareness Theory " on top of being a practical ${ }^{\wedge \prime \prime}$ by combining ${ }^{\wedge}$ Political Systems and Political Law ${ }^{\wedge}$ so that political consciousness will turn inton Consciousness Theory of Law "(Law Understanding Theory), which can be understood by every society, especially in regulatory compliance and adherence to the laws that have been set by the state. The new scheme is as follows:

1) The level of public awareness is able to influence the level of active political participation in every activity of government, including elections. The higher level of awareness of the Law Society, the level of active political participation will be higher, and vice versa, the lower the level of community legal kesadran precisely, the lower the level of the active political participation.

2) The political system can not stand alone without the presence and support of the Law of Political" ${ }^{\wedge \prime}$, that is Political, Legal capable of forming a systemic structure to organize the People to join and are subject to what the State wants, of course through the political system. Such as the creation of a specific statute, automatically after it is passed and enacted the people must be subject and obedient to the law, this is a passive Political Participation. Likewise on the establishment of the Law on obligatory Selects / Use of the right to vote in elections. This is of interest to investigate.

3) In the elections, the law on the obligation to use the right to vote is important, it does not mean the exclusion of human rights and forcing them to do certain things as if they were pressured to submit to the rule, but it is an effort to protect the rights of individuals as citizens Voters countries, namely between "1 and ${ }^{\wedge}$ Selected ${ }^{\wedge}$. Should not only give priority to the rights of voters, but remember potential leaders in the election has the right to choose, the objective is the harmonization of the relationship between voters and to be selected. In a sense, come to the polls for Voter is "Mandatory legal" whereas later who he would choose his "Sunnah".

\section{CONCLUSION}


1. Elections are not effective because in the Law on Election namely Act No. 7 of 2017, mentioned in Article 198, paragraph 1, which reads: "citizens who on election day are fulfilled age of 17 (seventeen) years or older, married, or have ever been married have the right to choose ". Obviously the words included are "right" and not "obligation". This led to an understanding of different laws in the community, especially understanding the extent of the right terminology, so that the ignorant masses to exercise their voting rights, as a result of high abstention figure.

2. Shura system offers a pretty good alternative to overcome the problems facing Indonesia, especially in terms of the use of the right to vote in elections. Shura system requires each individual and society that the majority of Muslims to exercise their voting rights in lifting and selecting candidates for leader as a responsibility he would be the importance of the voice he had and took part in participate actively in determining the candidate who is elected leader.

3. The Indonesian government should adopt a legal obligation to exercise their voting right in the legal political system as a shura in achieving the objectives of the country.

\section{BIBLIOGRAPHY}

Al-Qur'an Dan Terjemahnya, (Jakarta: Departemen Agama RI: 2015)

Abu Ya'la Al-Farra', Al-Ahkam Al-Sulthaniyah, (Kairo: Mustafa Bab Al-Halabi, 1963)

Ali Hasan al-'Ard, Sejarah dan Metodologi Tafsir, (Jakarta : Raja Grafindo Persada, 1994)

Anis Mashdurohatun, 2017, Hukum Kontrak, Ekonomi Syariah Dan Etika, Undip Press, Semarang.

Gunarto, 2018, Fair Consumer Protection, Balanced And Proportional In A Fixed E-Commerce Agreement Based On Justice Value, Scholars Journal Of Arts, Humanities And Social Sciences, India.

H.Rosjidi Ranggawidjaja, Restriction of Constitutional Right of Citizens to Choose and Selected in the Public Position Journal-Constitution PSKN FH Padjadjaran University, Volume II, Number 2, November 2010, Jakarta, FH Unpad with the Constitutional Court

Ibn Taymiyah, Al-Siyasah Al-Syari'ah, (Cairo: Dar Al-Stu'ban, 1980) 
Ifdhal Kasim, Hak sipil dan Politik Esai-Esai Pilihan, Cetakan Pertama, (Jakarta: Lembaga Studi dan Advokasi Masyarakat (ELSAM), 2001)

Kemenkumham. Partai Politik Dan Demokrasi Indonesia Menyongsong Pemilihan Umum 2014. Jurnal Legislasi Indonesia Vol.9 No.4 Desember 2014.

Handayani, I Gusti Ayu Ketut Rachmi, Edi As'Adi, Guntur Hamzah, Tommy Leonard, and Gunarto. "Relationship between energy consumption in international market and indonesia prices regulation." International Journal of Energy Economics and Policy 7, no. 5 (2017): 9-15.

Laksana, Andri Winjaya, and Suratman. "Analisis Yuridis Penyidikan Tindak Pidana Pornografi Di Era Digitalisasi. "Jurnal Pembaharuan Hukum I, no. 2 (2014): 169-77.

Mashdurohatun, Anis. "perlindungan hukum merek batik menuju aec 2015 ( suatu studi merek batik di kota pekalongan )" Jurnal Pembaharuan Hukum I, no. 2 (2015): $132-43$.

Norm Kelly dan Sefakor Ashiagbor, Partai Politik dan Demokrasi dalam Perspektif Teoritis dan Praktis. (Washington DC: National Democratic Institute., 2011)

Sri Endah Wahyuningsih, 2014, Restorative Justice System-Di Tingkat Penyidikan Tindak Pidana Lalu Lintas, Tunas Puitika Publishing, Brebes.

Teungku Muhammad Hasbi Ash-Shiddieqy, Sejarah dan Pengantar I/mu Al-Qur'an dan Tafsir, (Semarang: Pustaka Rizki Putra, 2009)

Act No. 39 of 1999 on Human Rights (HAM) 